that honour myself in matters of this kind, I shall decline any further paper controversy, and conclude with the following quotation: "Let he who is himself faultless cast the first stone." I have the honour to be, $\mathrm{Sir}$, your's obediently,

Thomas Frith.

* * We are not responsible either for the grammar or composition of our correspondent, but are quite willing to give him an opportunity of explaining in his own way his medical proceedings.

\section{THE KENSINGTON UNION.}

\section{To the Editor of ThE LANCET.}

SIr:-During a period of twenty-one years, in which I filled the office of parochial medical attendant of Fulham, I never re. fused to attend a pauper, when summoned, with or without an order. If the party were eligible, the document was obtained, and if not, I ceased or continued my attendance, according to the urgency of the case; I recommend my junior brethren to pursue the same plan; and, should they remain in office as long as I did, they will experience the pleasurable reflection of never having had a complaint against them.

$I$ possess the united testimony of the clergy and laity of the parish in support of my assertion. I am, Sir, your obedient ser. vant,

King's-road, Chelsea, Nov. 19, 1840.

\section{A FOURPENNY VACCINATOR.}

To the Editor of The La NCET.

Sir:-In The Lancet for Oct.2nd, you inserted a copy of an advertisement for a vaccinator for the Hyde district of the Stockport Union, whose services were to be remunerated by a SIXPENCE for each succEssFul case. Doubtless your readers regretted the mistaken economy of the guardians of that district, careful of pence, but careless of the health of the community; and many, perhaps, thought that such an offer would be treated with contempt, by the members of an enlightened profession. But, Sir, I regret, for the honour of the profession, that such is not the case, for a $\mathrm{Mr}$. Clubb, even sent in an offer to undertake the duties of vaccinator for that district at a lower premium, viz., for FouR PENCE per head for each successfol case. This $\mathrm{Mr}$. Clubb is also the medical attendant to a society, the members of which pay to the funds $a$ HALFPENNY $a-$ week each, for all necessary medicines, attendances, \&c., when illness attacks any or all of the members. He resides in Hazle Grove, near Stockport.

These clubs are very common in the north of England, and are called, par excellence,
"Boards of Health !" These matters, on account of their importance, will, perhaps, attract the notice of the council of the British Medical Association. I am, Sir, yours, obediently,

Nov. 20, 1840.

H. $\mathbf{H}$.

The New Vaccinátion Act,-The Poorlaw Guardians of St. Martin have appointed, as one of their vaccinators, a druggist, who holds the following valuable appointments : - "Chemist and Druggist to the Queen," "Agent for the West Middlesex Assurance Company," "s Agent for the Yorkshire Life Insurance Company," "Sole West-end Agent for Albinolo's Ointment," " Agent for Swaim's Panacea and Vermifuge," \&c. What will the doctors say to that?-British Em. pire Newspaper, Ocl. 31, 1840.

\section{UNIVERSITY COLLEGE HOSPITAL,}

MALIGNANT TUMOUR INVOLVING PART OF THE LOWER JAW.

G. W., a tall, spare man, about seventy years of age, was admitted November 8 , with a tumour on the right side of the lower jaw, of which he gave the following history: - He first noticed it about a year and a half or two years ago, when it was quite loose, rounded, and hard, like a nut, and neither painful nor tender. It was then situated under the base of the lower jaw, in the upper part of the neck. At first it increased very slowly, and, indeed, for several months after he first noticed its presence, it remained almost stationary. At the end of that time he began to feel shooting pains in the part, and he thought the swelling became larger. He accordiugly showed it to a surgeon, who recommended bathing it frequently with salt water; this he had continued to do until lately. Abont five or six months ago, the increase in the size of the tumour began to be more evident, and since then the growth has been more rapid. The patient says, that twenty-one weeks ago the tumour was loose, and of very inconsiderable size; but soon after it begun to grow so rapidly, he found he could no longer move it about under the skin, as it was then firmly fixed to the jaw, For the last few weeks he has suffered more than usual, the pains being of a shooting, lancinating kind. Indeed, his sufferings have been so great, that he has come to town from Hull for the purpose of having the jaw removed, if possible. While on his journey, the skin over the lower part of the tumour burst, and a small quantity of curdy matter escaped. A similar fluid has been continually discharging itself since. On examining the face, the first thing which appears is a cicatrix, slightly puckered on the right side of the lower lip, the same side 